\title{
Evaluation of the utilization of heated sewage sludge for peri-urban horticulture production in the Sahel of West Africa
}

\author{
Keiichi Hayashi ${ }^{\text {a,* }}$, Tahirou Abdoulaye ${ }^{\mathrm{b}, 1}$, Toshiyuki Wakatsuki ${ }^{\mathrm{c}, 2}$ \\ a ICRISAT-Niamey, BP 12 404, Niamey, Niger \\ ' INRAN DECO, BP 429, Niamey, Niger \\ ' Shimane University 1060, Nishikawatsu, Matsue, 690-8686 Shimane, Japan
}

\section{A R T I C L E I N F O}

\section{Article history:}

Received 7 May 2008

Received in revised form 2 June 2009

Accepted 14 August 2009

Available online 16 September 2009

\section{Keywords:}

Peri-urban horticulture

Heated sewage sledge (HSS)

Net returns

Millet-based cropping system

Sahel

\begin{abstract}
A B S T R A C T
Shortage of organic matter hinders agricultural production in the Sahel, and this lack of enough organic matter is more severe for peri-urban horticulture, which depends heavily on it. Alternative sources of organic matter that offer new options for peri-urban horticulture can help reduce the potential for conflict over finite resources between traditional crop production and peri-urban horticulture. Both agronomic and economic evaluations of an organic amendment called heated sewage sludge (HSS) were conducted in the research station of International Crops Research Institute for the Semi-Arid Tropics (ICRISAT)-Niamey, Niger, West Africa. For this study, HSS, a material imported from Japan, applied at a dosage application equivalent to $20.0 \mathrm{~kg} 100 \mathrm{~m}^{-2}$ on lettuce fields led to production levels as high as those of conventional methods, and the yield became even higher than those of conventional methods when the dosage was increased to $50.0 \mathrm{~kg} 100 \mathrm{~m}^{-2}$ and $100.0 \mathrm{~kg} 100 \mathrm{~m}^{-2}$. Even though HSS was imported, its benefits outweighed its cost, as evidenced by the positive net returns. Since profitability in peri-urban horticulture is much higher than that of traditional crop production, the results of this study imply that if adopted, the use of HSS can lead to increased availability of organic matter for traditional cropping systems.
\end{abstract}

() 2009 Elsevier Ltd. All rights reserved.

\section{Introduction}

Peri-urban horticulture is becoming an important practice in the sub-Saharan Africa as it contributes to poverty alleviation for subsistence smallholder households by enhancing their income generation (World Vegetable Center, 2007). However, for resource-poor countries such as Niger, insufficient organic matter supply in peri-urban agriculture is a problem as production requires large quantities of organic amendments using organic matters such as farmyard manure and crop residues.

Farmyard manure and crop residues are two of the traditionally used organic resources in Niger, and both are important for upland production of millet, sorghum, and cowpea. Many scientists have pointed out the importance of those organic matters for highly degraded sandy soils (Bationo and Mokwunye, 1991a; Bationo and Buerkert, 2001; Yamoah, 1998) and concluded that their judicious

\footnotetext{
* Corresponding author. Present address: Japan International Research Center for Agricultural Sciences (JIRCAS), 1-1 Ohwashi, Tsukuba, Ibaraki 305-8686, Japan. Tel./ fax: +81298386355 .

E-mail address: khayash@jircas.affrc.go.jp (K. Hayashi).

1 Present address: IITA-Kano, Sabo Bakin Zuwo Road, PMB 3112, Kano, Nigeria.

2 Present address: Kinki University, School of Agriculture, 3327-204 Naka-Machi, Nara 631-8505, Japan.
}

utilization in agriculture due to the scarcity of existing resources is critical for maintaining or increasing production (Schlecht et al., 2004). Equally critical are issues of income generation and utilization of crop residue for livestock feed, which results in large quantities of crop residues being sold by farmers (Bationo and Mokwunye, 1991b). Since agricultural production in the country depends highly on upland rainfed cereal production, there is a serious competition between the traditional crop production and periurban horticulture for the usage of the remaining available organic matter. Agricultural research has been looking into this problem and especially trying to find how to make organic amendments available to both traditional crop production and peri-urban horticulture as both are very important to increase food security and income.

Heated sewage sludge (HSS) as an organic amendment for agricultural production has been studied in Japan, and its profitability has been documented (Moritsuka et al., 2006; Matsuoka et al., 2006). Despite its profitability, the amount of this material for the purpose of agriculture or reforestation was estimated to account for only $14 \%$ (Moritsuka et al., 2006), and this was due to the slackening in growth of agriculture in Japan. Even though HSS could potentially help enhance agriculture production, it has never been tested for agronomic and economic performance in Niger. 
The objective of this study is to evaluate the agronomic and economic performance of HSS, imported from Japan, in peri-urban horticulture in the Sahel.

\section{Materials and methods}

\subsection{Site description}

The experiment was conducted at the research station of International Crops Research Institute for the Semi-Arid Tropics (ICRISAT)-Niamey, Niger, West Africa, which is located in the Sahelian agro-ecological zone. In this region, there are two main seasons, a rainy season from June to October and a dry season from November to May. A mono-modal rainfall pattern during the rainy season has an annual average of $560 \mathrm{~mm}$, the highest being the month of August. Agriculture is the most important economic activity of Niger, with $90 \%$ of the population directly engaged in different agricultural production activities. Rainfed production is the main agricultural system for cereal crops such as millet (Pennisetum glaucum) and cowpea (Vigna unguiculata), and the cultivated area is approximately $99 \%$ of the total agricultural area and $70 \%$ of the total agricultural production. Although vegetable production used to be the alternative production system during the dry season, it is becoming an important income-generating activity for smallholder households of the peri-urban area due to changes in the consumption patterns among urban populations. The main types of vegetables grown in Niger and their annual production are shown in Fig. 1. Lettuce is among the most frequently produced vegetables in the country and is being used for this evaluation.

\subsection{Heated sewage sludge (HSS)}

Kurita Co., Ltd. in Japan produced a HSS derived from human night soils and urine treatment plants. This is a new technology in which sewage sludge is heated at comparatively low temperatures of approximately $150-180^{\circ} \mathrm{C}$, a process that eliminates negative factors such as high moisture content, offensive smell, pathogenic problems in sewage sludge, and bulkiness, which are conventional constraints for utilization of such material. Because the process does not involve burning, nitrogen contents are never decreased (Matsuoka et al., 2006). After the heating, the material

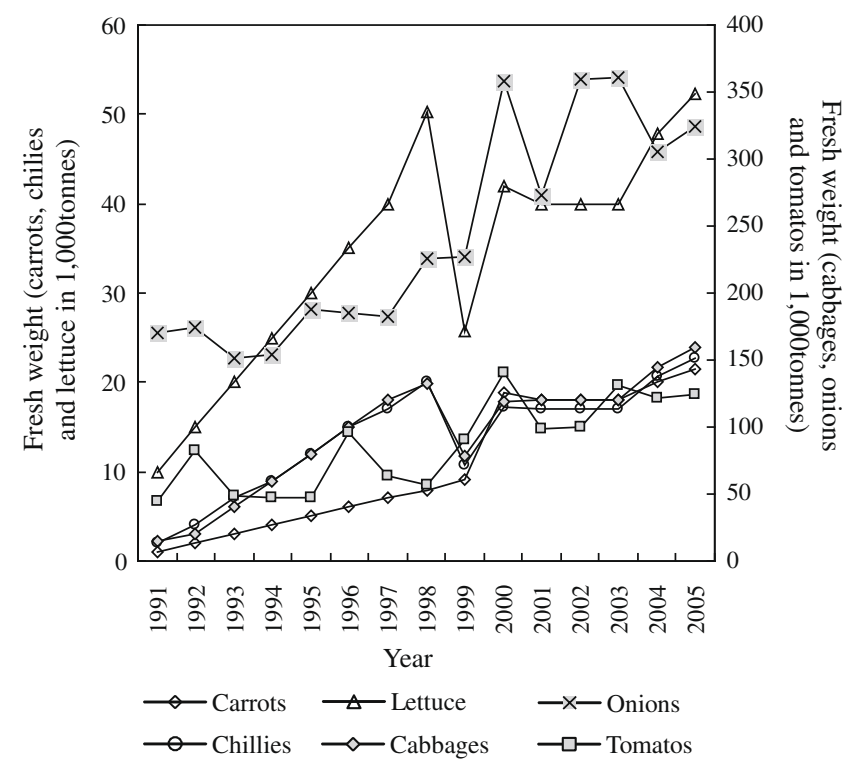

Fig. 1. The 15-year evolution of national production of different vegetables in Niger based on the FAOSTAT (FAO, 2007).
Table 1

Nutrient facts and assessment of heavy metals content in HSS along with supervisory law of fertilizer in Japan. Referred from Matsui et al. (unpublished data).

\begin{tabular}{lcll}
\hline Parameter & Results & Unit & Threshold value \\
\hline $\mathrm{pH}$ & 6.1 & $\mathrm{HS}: \mathrm{H}_{2} \mathrm{O}=1: 10$ & - \\
$\mathrm{O} . \mathrm{M}^{\mathrm{a}}$ & 2.34 & $(\%)$ & - \\
$\mathrm{M}^{\mathrm{b}}$ & 69.23 & $(\%)$ & - \\
$\mathrm{T}-\mathrm{N}$ & 5.52 & $(\%)$ & - \\
$\mathrm{P}_{2} \mathrm{O}_{5}$ & 5.08 & $(\%)$ & - \\
$\mathrm{K}_{2} \mathrm{O}$ & 0.31 & $(\%)$ & - \\
$\mathrm{CaO}$ & 1.89 & $(\%)$ & - \\
$\mathrm{MgO}$ & 0.51 & $(\%)$ & - \\
Organic C & 33.59 & $(\%)$ & - \\
$\mathrm{Alkalinity}$ & 2.4 & $(\%)$ & - \\
$\mathrm{C} / \mathrm{N}$ & 6.1 & - & - \\
$\mathrm{Hg}$ & 1.05 & $\mathrm{mg} / \mathrm{kg}$ DMW & 2 \\
$\mathrm{As}$ & 2.7 & mg/kg DMW & 50 \\
$\mathrm{Cd}$ & 2.2 & mg/kg DMW & 5 \\
\hline
\end{tabular}

a Organic matter content.

b Moisture content.

becomes a grain-like substance and can be easily applied to the field as a chemical fertilizer. HSS contains higher amounts of nitrogen and available phosphorous compared to local materials such as manure, and its heavy metal contents are below the threshold value (Table 1). HSS was used in previous studies that showed high potential in production of komatsuna plants (Brassica campestris L. var. rapa) (Moritsuka et al., 2006; Matsuoka et al., 2006). HSS for the study was purchased from the Tsutsumigadani center, the Association of environmental hygiene in Kyonan subdivision in Japan at a price of US\$ 0.13 per $20 \mathrm{~kg}$.

\subsection{Experimental design}

The experiment was conducted from December 2002 to February 2003 , which is the season for vegetable production in Niger. A plastic pot $(0.22 \mathrm{~m}$ in diameter and $0.23 \mathrm{~m}$ in depth) was used, with the soil taken from the experimental field of the research station. The chemical characteristics of the soil used for the experiment were as follows: $\mathrm{pH}\left(\mathrm{H}_{2} \mathrm{O}\right)=5.3,0.9 \%$ of organic carbon content, $4.2 \mathrm{mg} \mathrm{kg}^{-1}$ of available phosphorous (Bray 1 method), and $160.6 \mathrm{mg} \mathrm{kg}^{-1}$ of total nitrogen. The experiment was designed in a split-plot with varieties as a main factor and fertilization as a sub-factor. The lettuce varieties Noga (NG), Aviram (AV), and Great Lakes (GL) were obtained from ICRISAT-Niger and used for the experiment. Dosages of HSS application were as follows: T1 $=0.5$

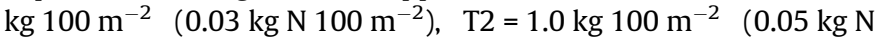

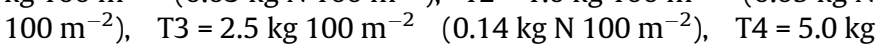

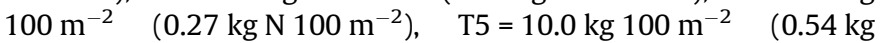
$\left.\mathrm{N} 100 \mathrm{~m}^{-2}\right), \quad \mathrm{T} 6=20.0 \mathrm{~kg} 100 \mathrm{~m}^{-2}\left(1.08 \mathrm{~kg} \mathrm{~N} 100 \mathrm{~m}^{-2}\right), \quad \mathrm{T} 7=50.0$

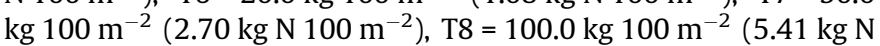
$\left.100 \mathrm{~m}^{-2}\right)$. A conventional application method with $3.75 \mathrm{~kg}$ of NPK (N: $\left.\mathrm{P}_{2} \mathrm{O}_{5}: \mathrm{K}_{2} \mathrm{O}=15: 15: 15\right) 100 \mathrm{~m}^{-2}$ (T9; $0.56 \mathrm{~kg} \mathrm{~N} 100 \mathrm{~m}^{-2}$ ) and $3.75 \mathrm{~kg}$ of NKP $100 \mathrm{~m}^{-2}+200 \mathrm{~kg}$ of farmyard manure (FM) $100 \mathrm{~m}^{-2}$ (control; $2.56 \mathrm{~kg} \mathrm{~N} 100 \mathrm{~m}^{-2}$ ) were also designed as a comparison to the treatments. 0.41 of irrigated water per day were applied to each pot throughout the period of experiment.

\subsection{Economic analysis}

Net return was used to determine the feasibility for the utilization of HSS in peri-urban horticulture of the Sahel. Net return was calculated with the following formula:

$r=R-\sum C$

where $r$ is net return, $R$ is the revenue obtained by multiplying per unit price and yield, and $C$ is the cumulative total cost estimated 
Table 2

Parameters for economic analysis.

\begin{tabular}{llc}
\hline Parameter & $\begin{array}{l}\text { Quantity } \\
\left(\mathrm{kg} 100 \mathrm{~m}^{-2}\right)\end{array}$ & $\begin{array}{c}\text { Price } \\
\left(\mathrm{US \$} \mathrm{kg} \mathrm{kg}^{-1}\right.\end{array}$ \\
\hline (1) Lettuce product & - & 2.13 \\
(2) Lettuce seed & 0.003 & 127.66 \\
(3) Field work (PDE) & $0.2^{\mathrm{b}}$ & $3.19^{\mathrm{b}}$ \\
(4) Organic amendment (Cow manure) & 200 & 0.21 \\
(5) Inorganic amendment (NPK) & 3.75 & 0.55 \\
(6) Humificated sludge & 20 & $0.4^{\mathrm{c}}$ \\
\hline
\end{tabular}

a Retailed price, 1 US\$ $=470$ FCFA

b Unit is PDE $100 \mathrm{~m}^{-2}$ for quantity and US\$ $\mathrm{PDE}^{-1}$ for price.

c Estimation based on total cost of shipment.

with each unit price presented in Table 2. Actually, this net return should be understood as a return to capital and management because their opportunity costs were not accounted for in the calculations.

Two pricing scenarios for the HSS were used. In scenario 1, it was assumed that the HSS would have the same price as a locally available inorganic fertilizer, NPK (15-15-15) formula in this case. The price of NPK was a direct quote from Centrale d'Approvisionement du Niger (CAN), a government agency in charge of importing and selling fertilizers and other inputs.

In scenario 2, the Cost-Insurance-Freight value (CIF) of direct importation from Japan by a private agent was used. The CIF was estimated by MAERSK (an international shipping company) in Niamey, and the estimated cost was 11,659.13 US\$ per 40 tones size of container. Note that no import tax was added since Niger has stopped taxing agricultural materials in an effort to boost production.

The yields obtained in the experiment were converted to the $100 \mathrm{~m}^{-2}$ one based on the recommended density for lettuce production in Niger of 2500 hills $100 \mathrm{~m}^{-2}$. An average price of lettuce of $2.1 \mathrm{US} \$ \mathrm{~kg}^{-1}$ was used. In addition, given the high seasonal variation in lettuce prices, a sensitivity analysis was conducted using a $50 \%$ increase and decrease in lettuce price.

\section{Results}

\subsection{Performance of heated sewage sludge (HSS) on vegetable production}

The fresh weight of lettuce production is shown in Table 3. With conventional practice (designated as control), the varieties NG, AV, and GL produced 77.3, 94.7, and $95.3 \mathrm{~kg} 100 \mathrm{~m}^{-2}$, respectively.

Table 3

Comparison of productivity of lettuce production between conventional practice and different dosages of HSS applications.

\begin{tabular}{|c|c|c|c|c|c|c|}
\hline \multirow[t]{2}{*}{ Treatment } & \multicolumn{6}{|c|}{ Yield $\left(\mathrm{kg} 100 \mathrm{~m}^{-2}\right)^{\mathrm{a}}$} \\
\hline & NG & & AV & & GL & \\
\hline Control $\left(2.56 \mathrm{~kg} \mathrm{~N} 100 \mathrm{~m}^{-2}\right)$ & 77.27 & c & 94.67 & $\mathrm{~cd}$ & 95.29 & c \\
\hline $\mathrm{T} 1\left(0.03 \mathrm{~kg} \mathrm{~N} 100 \mathrm{~m}^{-2}\right)$ & 1.74 & $\mathrm{~d}$ & 1.87 & $\mathrm{e}$ & 1.44 & $\mathrm{e}$ \\
\hline $\mathrm{T} 2\left(0.05 \mathrm{~kg} \mathrm{~N} 100 \mathrm{~m}^{-2}\right)$ & 2.16 & $\mathrm{~d}$ & 2.70 & $\mathrm{e}$ & 2.21 & $\mathrm{e}$ \\
\hline T3 $\left(0.14 \mathrm{~kg} \mathrm{~N} 100 \mathrm{~m}^{-2}\right)$ & 1.17 & $\mathrm{~d}$ & 2.96 & $\mathrm{e}$ & 3.18 & e \\
\hline $\mathrm{T} 4\left(0.27 \mathrm{~kg} \mathrm{~N} 100 \mathrm{~m}^{-2}\right)$ & 2.04 & $\mathrm{~d}$ & 4.38 & $\mathrm{e}$ & 6.54 & $\mathrm{e}$ \\
\hline T5 $\left(0.54 \mathrm{~kg} \mathrm{~N} 100 \mathrm{~m}^{-2}\right)$ & 3.14 & $\mathrm{~d}$ & 25.88 & $\mathrm{e}$ & 17.48 & de \\
\hline T6 (1.08kg N $\left.100 \mathrm{~m}^{-2}\right)$ & 30.98 & $\mathrm{~cd}$ & 98.86 & c & 77.70 & $\mathrm{~cd}$ \\
\hline $\mathrm{T} 7\left(2.70 \mathrm{~kg} \mathrm{~N} 100 \mathrm{~m}^{-2}\right)$ & 179.67 & $\mathrm{~b}$ & 334.78 & b & 286.14 & $\mathrm{~b}$ \\
\hline $\mathrm{T} 8\left(5.41 \mathrm{~kg} \mathrm{~N} 100 \mathrm{~m}^{-2}\right)$ & 290.05 & $\mathrm{a}$ & 430.50 & $\mathrm{a}$ & 421.44 & $\mathrm{a}$ \\
\hline T9 $\left(0.56 \mathrm{~kg} \mathrm{~N} 100 \mathrm{~m}^{-2}\right)$ & 2.40 & $\mathrm{~d}$ & 18.69 & $\mathrm{e}$ & 16.13 & de \\
\hline Mean & 57.04 & $\mathrm{a}$ & 102.29 & $\mathrm{~b}$ & 92.47 & $a b$ \\
\hline Variety & $\mathrm{P}<0.001$ & & & & & \\
\hline Treat & $\mathrm{P}<0.001$ & & & & & \\
\hline Variety $\mathrm{x}$ Treat & $P=0.012$ & & & & & \\
\hline
\end{tabular}

Yield data followed by same alphabet shows no significant difference at $5 \%$ by DMRT.

a Average of four replications
With treatments T1-T5 where dosages of nitrogen in HSS applied ranged from 0.03 to $0.54 \mathrm{~kg} 100 \mathrm{~m}^{-2}$, yield for each variety was still far below that of the control. The production started increasing with $\mathrm{T} 6$ and became as high as that of the control. It became even higher when the dosage of nitrogen was further increased to $2.70 \mathrm{~kg} 100 \mathrm{~m}^{-2}$ (T7) and $5.41 \mathrm{~kg} 100 \mathrm{~m}^{-2}$ (T8). However, production decreased again when fertilization was done using only inorganic fertilizer, such as NPK (T9).

The results of statistical analysis on analysis of variance (ANOVA) test showed that there is a significant difference among varieties and treatments. Combined effects of variety and treatment were also significant because of obtained $p$ value (0.012). According to the results of Duncan's multiple range test (DMRT), all varieties produced much less than control when dosage was less than

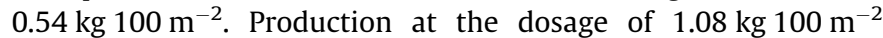
showed a non-significant difference from control, and it became significantly higher than control when dosages reached $2.70 \mathrm{~kg} 100 \mathrm{~m}^{-2}$ and $5.41 \mathrm{~kg} 100 \mathrm{~m}^{-2}$. Among the varieties, AV and NG were significantly different while AV and GL or GL and NG were not. Fig. 2 shows the response curve of the lettuce production to different dosages of nitrogen. This figure indicates that the production of $\mathrm{AV}$ and GL had better response to the increase in nitrogen dosage than that of NG, and this implies better efficiency for those varieties in nutrient utilization.

\subsection{Net returns of conventional production compared to HSS in different scenarios}

According to production results, T6, T7, and T8 had the highest production among all treatments, and thus only these treatments were evaluated for profitability. Net returns for each treatment were calculated based on the total cost and revenue as explained above and results compared with those of the conventional method. Table 4 shows that the revenue of T6 in scenario 1 was almost the same amount as the control, although its total cost was $74 \%$ lower than that of control. Only NG in this treatment resulted in lower revenue compared to the control. When the dosage of HSS was increased to $50 \mathrm{~kg} 100 \mathrm{~m}^{-2}$ (T7), total cost remained 39\% lower than that of control, but the revenue for NG, AV, and GL became $134 \%, 254 \%$, and $200 \%$ higher than that of control, respectively. At the dosage of $100 \mathrm{~kg} 100 \mathrm{~m}^{-2}$ (T8), revenue for NG, AV, and GL became $279 \%, 356 \%$, and $342 \%$ higher than that of control respectively while total cost increased by only $22 \%$. A small difference in net return between the two scenarios was noted for all treatments. In scenario 2, total cost was considerably lower compared to the control and even T8 showed 11\% lower cost than the control in spite of being the largest dosage among the HSS treatments.

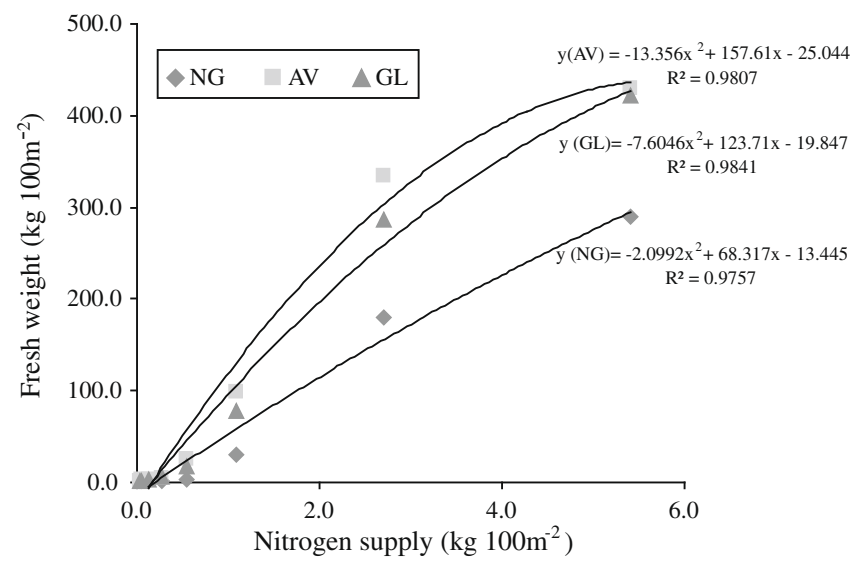

Fig. 2. Response of three varieties of lettuce to different dosage of nitrogen through HSS application. 
Table 4

Total cost and net return in peri-urban horticulture with the application of HSS.

\begin{tabular}{|c|c|c|c|c|c|c|c|}
\hline \multirow[t]{2}{*}{ Variety } & & \multirow[t]{2}{*}{$\begin{array}{l}\text { Yield } \\
\left(\mathrm{kg} 100 \mathrm{~m}^{-2}\right)\end{array}$} & \multirow[t]{2}{*}{$\begin{array}{l}\text { Revenue } \\
\left(\text { US\$ } 100 \mathrm{~m}^{-2} \text { ) }\right.\end{array}$} & \multicolumn{2}{|c|}{$\begin{array}{l}\text { Total cost } \\
\left(\text { US } \$ 100 \mathrm{~m}^{-2}\right)^{\mathrm{a}}\end{array}$} & \multicolumn{2}{|c|}{$\begin{array}{l}\text { Net return } \\
\left(\text { US } \$ 100 \mathrm{~m}^{-2}\right)\end{array}$} \\
\hline & & & & Scenario 1 & Scenario 2 & Scenario 1 & Scenario 2 \\
\hline \multirow{3}{*}{$\begin{array}{l}\text { Control } \\
\qquad\left(\text { FM } 200 \mathrm{~kg} 100 \mathrm{~m}^{-2} \text {, }\right. \\
\left.\text { NPK } 3.75 \mathrm{~kg} 100 \mathrm{~m}^{-2}\right)\end{array}$} & NG & 77 & 163 & 46 & - & 117 & - \\
\hline & AV & 95 & 201 & 46 & - & 155 & - \\
\hline & GL & 95 & 203 & 46 & - & 157 & - \\
\hline \multirow{3}{*}{ T6 $\left(\mathrm{HS} 20 \mathrm{~kg} 100 \mathrm{~m}^{-2}\right)$} & NG & 31 & 66 & 12 & 9 & 54 & 57 \\
\hline & AV & 99 & 210 & 12 & 9 & 198 & 201 \\
\hline & GL & 78 & 165 & 12 & 9 & 153 & 156 \\
\hline \multirow{3}{*}{$\begin{array}{l}\mathrm{T} 7 \\
\left(\mathrm{HS} 50 \mathrm{~kg} 100 \mathrm{~m}^{-2}\right)\end{array}$} & NG & 180 & 382 & 28 & 21 & 354 & 361 \\
\hline & AV & 335 & 712 & 28 & 21 & 684 & 691 \\
\hline & GL & 286 & 609 & 28 & 21 & 581 & 588 \\
\hline \multirow{3}{*}{$\begin{array}{l}\text { T8 } \\
\qquad\left(\mathrm{HS} 100 \mathrm{~kg} 100 \mathrm{~m}^{-2}\right)\end{array}$} & NG & 290 & 617 & 56 & 41 & 561 & 576 \\
\hline & AV & 431 & 916 & 56 & 41 & 860 & 875 \\
\hline & GL & 421 & 897 & 56 & 41 & 841 & 856 \\
\hline
\end{tabular}

a Scenario 1 unit price of HSS $=0.39 \mathrm{US} \$ \mathrm{~kg}^{-1}$, scenario $2 \mathrm{HSS}=0.28 \mathrm{US} \$ \mathrm{~kg}^{-1}$.

The net return results indicate that for T6, only the variety AV did better in terms of returns than the conventional. In fact, for the other two varieties, at the T6 dosage level HSS return was significantly lower for the variety NG and slightly lower than that of the control treatment for the variety GL. At the higher application rates of $\mathrm{T} 7$ and T8, all varieties have much higher returns than the conventional practice (Table 4). In the second scenario, with a lower price for the HSS, the results remained the same in terms of ranking of the treatments.

A lettuce price sensitivity analysis was conducted to account for the considerable seasonable price variability of lettuce in Niger. When lettuce price was increased by $50 \%$, only the magnitude of the net returns was increased, but that did not lead to any change in the choice of treatments. The HSS treatments at high dosage (T7 and T8) are still better than the control. Even when lettuce was made cheaper by $50 \%$, the changes were negligible due to the big differences in productivity noted earlier.

\section{Discussion}

Vegetable production in peri-urban horticulture (available only to a limited number of farmers in Niger) is a better alternative than traditional rainfed crop production for generating and enhancing income of the subsistence farmers in the region who have access to it. Conventional vegetable production exhibited profitability through its net return, which ranged from 117 to 156 US\$ $100 \mathrm{~m}^{-2}$ in our study. According to the previous study (Hayashi et al., 2008), traditional crop production of millet, which is the main staple crop in Niger, could only obtain its net return with 0.025 US\$ $100 \mathrm{~m}^{-2}$ without fertilization and 0.079 US $\$ 100 \mathrm{~m}^{-2}$ with micro-dosing fertilizer application. This gap in benefits might lead to a situation of skewed resource allocation toward peri-urban horticulture compared to traditional cereals production. According to a survey of local producers in Niger, even small-scale peri-urban producers tend to use intensive management by using more inputs such as time, labor, and fertilizer because they are aware of the higher profitability in peri-urban horticulture (data not shown). This will lead to a critical situation for traditional cereals production, which cannot compete with horticulture in terms of income generation. Thus, fewer of the inputs will go to traditional cereal production.

The importance of organic amendment in peri-urban horticulture is well recognized (Weinberger and Lumpkin, 2007), and this was confirmed through the study. The lettuce production was far below the level of conventional methods when manure was not applied along with inorganic fertilizer. This complementarity was recognized by farmers and led to increased prices of manure for peri-urban horticultural activities. With the increased value of manure, a serious competition has developed between its usages, especially for traditional cereals production. On the other hand, the organic resource in traditional agriculture is considered one of the insufficient resources in this country (Schlecht et al., 2004), and this constraint has been discussed over the years through different studies (Bationo and Buerkert, 2001; Yamoah, 1998). Soil fertility is one of the critical constraints to increased agricultural production in Niger, and utilization of locally available organic resources such as manure is imperative to mitigate the problem. Most local farmers are subsistence farmers and, in the current conditions, can afford to buy few or no amendments purchase inputs (Abdoulaye and Sanders, 2006; Hayashi et al., 2008), which makes organic matters more critical for tackling the soil fertility problem. Nonetheless, increase in activities in peri-urban horticulture will make organic resources scarcer than before for rainfed production. Alternative sources of organic matter such as HSS can play a crucial role in mitigating this serious problem and creating a more balanced system in organic matter supply.

Despite high cost due to importation from overseas, our study showed utilization of HSS is profitable, as evidenced by the positive net return. Although the experiment was designed in pot scale and thus the economic evaluation was carried out under controlled conditions, obtained information can be used as a guideline to develop a suitable technology/system for HSS application. Furthermore, it will probably be ultimately even cheaper for Niger to find ways to produce HSS locally and make it available to its horticulture farmers. In the meantime, the unit price could be reduced through using an Official Development Assistance (ODA) scheme based on bilateral agreement between Niger and Japan. An economic feasibility analysis taking into account cost of production factors in Niger should provide a better answer to the question of local production versus import of HSS.

\section{Conclusion}

Alternative sources of organic matter for peri-urban horticulture are needed in the Sahel to reduce the competition on finite resources between the traditional and a more modern production system. This study has shown that HSS, an imported material from Japan, can lead to lettuce production as high as the conventional production practice at a dosage rate of $20.0 \mathrm{~kg} 100 \mathrm{~m}^{-2}$. Production

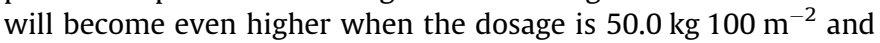
$100.0 \mathrm{~kg} 100 \mathrm{~m}^{-2}$. Although HSS needs to be imported from overseas, it is more profitable to use than the control practice, even at a higher dosage. Since peri-urban horticulture is much more profitable than traditional crop production, more investment in purchased organic amendment could be possible in order to 
maintain required nutrients while leaving the farmyard manure to the traditional system. In the near future, following economic feasibility studies, this organic amendment could be produced locally in West Africa because its production process of controlled heating is simple, and it is hoped that this can lower its cost and help disseminate this organic material in the Sahel of West Africa.

\section{Acknowledgements}

We are grateful for the financial support of the Japan Society for the Promotion of Science (JSPS) and the Ministry of Education, Culture, Sports, Science and Technology, Japan (MEXT) (Grant-in- aid Nos. 15101002 and 19002001). The views expressed in this paper are those of the authors and do not necessarily reflect those of their institutions. We are also grateful to Dr. Fatondji Dougbedji of ICRISAT-Niamey for his help during the experiment. We thank also the two anonymous referees and the editor of this journal for providing valuable comments that have helped to improve this paper. Any mistake or errors are the authors'.

\section{References}

Abdoulaye, T., Sanders, J.H., 2006. New technologies, marketing strategies and public policy for traditional food crops: millet in Niger. Agricultural Systems 90, 272-292.
Bationo, A., Mokwunye, A.U., 1991a. Alleviating soil fertility constraints to increase crop production in West Africa: the experience in the Sahel. Fertilizer Research 29, 95-115.

Bationo, A., Mokwunye, A.U., 1991b. Role of manures and crop residue in alleviating soil fertility constraints to crop production: with special reference to the Sahelian and Sudanian zones of West Africa. Fertilizer Research 29, 117-125.

Bationo, A., Buerkert, A., 2001. Soil organic carbon management for sustainable land use in Sudano-Sahelian West Africa. Nutrient Cycling in Agroecosystems 61, $131-142$.

FAO, 2007. FAOSTAT, ${ }^{\circ}$ FAO Statistics Division 2007. <http://faostat.fao.org/site/567/ default.aspx\#ancor> (accessed 17.08.07.).

Hayashi, K., Abdoulaye, T., Gerard, B., Bationo, A., 2008. Evaluation of application timing in fertilizer micro-dosing technology on millet production in Niger, West Africa. Nutrient Cycling in Agroecosystems 80, 257-265.

Matsuoka, K., Moritsuka, N., Masunaga, T., Matsui, K., Wakatsuki, T., 2006. Effect of heating treatment on nitrogen mineralization from sewage sludge. Soil Science and Plant Nutrition 52 (4), 519-527.

Moritsuka, N., Matsuoka, K., Matsumoto, S., Masunaga, T., Matsui, K., Wakatsuki, T., 2006. Effects of the application of heated sewage sludge on soil nutrient supply to plants. Soil Science and Plant Nutrition 52 (4), 528-539.

Schlecht, E., Hiernaux, P., Achard, F., Turner, M.D., 2004. Livestock related nutrient budgets within village territories in western Niger. Nutrient Cycling in Agroecosystems 68, 199-211.

Weinberger, K., Lumpkin, T.A., 2007. Diversification into horticulture and poverty reduction: a research agenda. World Development 35, 1464-1480.

World Vegetable Center, 2007. Joint Efforts that will improve the Livelihoods of Millions in Africa and Other Developing Countries. <http://www.globalhort.org/ news-events/news/\#news-6> (accessed Dec 2007).

Yamoah, C.F., 1998. Rotation effect on sorghum response to nitrogen fertilizer unde different rainfall and temperature environments. Agriculture Ecosystem and Environment 68, 233-243. 